\title{
Study Of The Use Of Plants For Treatment In The Community
}

\author{
Ali Rakhman Hakim ${ }^{1}$, Mustaqimah ${ }^{2}$ \\ \{alirakhmanhakim@unism.ac.id ${ }^{1}$, mustaqimah@unism.ac.id² \\ Pharmacy Departement of Sari Mulia University, Banjarmasin, Indonesia ${ }^{1,2}$
}

\begin{abstract}
This study aims to identified parts of plants that are widely used and how they are used by the community to treat diseases. This research is a qualitative research. The research data is obtained by interviewing the community directly. The results of this study are leaves are the most widely used plant parts and how to use them is by boiling. The use of leaves parts from plants for treatment indirectly the community has maintained the preservation of these plants in the community.
\end{abstract}

Keywoard: community, plants, treatment

\section{Introduction}

Science and technology in medicine and pharmacy are developing very rapidly. This allows the healing process of a disease to take place quickly and safely. Modern urban society has benefited greatly from this development. Communities in the villages also benefit from the advancement of science. However, the people in the village still maintain local wisdom in their area. People in the village still use plants around them to treat a disease and this is included in the field of ethnopharmacology. Ethnopharmacological discoveries and natural medicines remain the foundation of drug discovery at this time. Many modern medicines originate from traditional medicine and ethnopharmacology [1]. Tropical primary forests are often regarded as the most important habitat for traditional communities to collect medicinal plants [2].

\section{Research Methods}

The research method used was qualitative by interview. The respondents interviewed were people from Banjarmasin, Gambut, Danau Salak, and Banjarbaru. The number of respondents has been determined by researchers by considering the purpose and time available [3] [4]. The information to be obtained during the interview focuses on the name of the plant, the part of the plant used, and the properties of the plant. 


\section{Result}

Table 1. Plant names, Parts used, and benefit

\begin{tabular}{|c|c|c|c|}
\hline No & Plants & Parts Used & Benefit \\
\hline 1 & cocor bebek (Bryophyllum pinnatum) & Leaf & $\begin{array}{l}\text { Antipyretics, } \\
\text { Antiseptics, Thrush, } \\
\text { Ulcers }\end{array}$ \\
\hline 2 & Kembang Sepatu (Hibiscus rosa sinensis) & Leaf & Antipyretics \\
\hline 3 & Binahong (Bassela rubra linn) & Leaf & $\begin{array}{l}\text { Anti-Inflammatory, } \\
\text { Antihypertensive, } \\
\text { Antidiabetic Mellitus } \\
\end{array}$ \\
\hline 4 & Tapak Dara (Catharanthus roseus $(L)$ don & Leaf & Anti Cancer \\
\hline 5 & Kencur (Kaempreria galanga L) & Rhizome & Catch A Cold, Cough \\
\hline 6 & Suruhan (Paperomia pellucida $L$ ) & Leaf & Uric Acid \\
\hline 7 & Kumis kucing (Orthosiphon aristatus) & Leaf & Diuretic \\
\hline 8 & Beluntas (Pluchea indica) & Leaf & Antihypertensive \\
\hline 9 & Meniran (Phyllantus urinaria) & Leaf & Diuretic \\
\hline 10 & Sirsak (Annona muricata) & Leaf & Antihypertensive \\
\hline 11 & Ciplukan (Physalis peruviana) & Leaf & Pain In Kidney Stones \\
\hline 12 & Jambu biji (Psidium guajava) & Leaf & Antidiarrheal \\
\hline 13 & Jahe (Zingiber officinale) & Rhizome & $\begin{array}{l}\text { Anti-Inflammatory, } \\
\text { Karminativa }\end{array}$ \\
\hline 14 & Mangkokan (Nothopanax scutellarium) & Leaf & $\begin{array}{l}\text { Anti-Inflammatory, } \\
\text { Antibiotic }\end{array}$ \\
\hline 15 & Belimbing wuluh (Averrhoa bilimbi) & Leaf & $\begin{array}{l}\text { Antibiotics, } \\
\text { Antifungals }\end{array}$ \\
\hline 16 & Sirih (piper betle) & Leaf & $\begin{array}{l}\text { Antipyretic, Antiseptic, } \\
\text { Antiinflammatory, } \\
\text { Colds, Antihistamines }\end{array}$ \\
\hline 17 & Serai wangi (Cymbopogon nardus) & Leaf & Antiinflammatory \\
\hline 18 & Lidah buaya (Aloe barbadensis milleer) & Aloe Vera Meat Slime & To Nourish Hair \\
\hline 19 & temulawak (Curcuma xantorrhiza) & Rhizome & $\begin{array}{l}\text { Blood Circulation, } \\
\text { Appetite Enhancer }\end{array}$ \\
\hline 20 & Sambiloto (Andographis paniculata) & Leaf & $\begin{array}{l}\text { Antihypertensive, } \\
\text { Antidiabetic Mellitus }\end{array}$ \\
\hline
\end{tabular}




\begin{tabular}{|c|c|c|c|}
\hline 21 & Keji Beling (Sericocalyx crispus L) & Leaf & Antiinflammatory \\
\hline 22 & Dewandru (Eugenia uniflora) & Leaf & $\begin{array}{l}\text { Antihypertensive, } \\
\text { Antidiabetic Mellitus, } \\
\text { Antihyperlipidemia }\end{array}$ \\
\hline 23 & Papaya (Carica papaya) & Sap And Flowers & Antiseptic \\
\hline 24 & Gelinggang (Cassia alata) & Leaf & Antihistamine \\
\hline 25 & mengkudu (Morinda citrifolia) & Fruit And Root & Antihypertensive \\
\hline 26 & Bawang Putih (Allium Sativum) & Bulbs & Antihypertensive \\
\hline 27 & Ketumbar (Coriandri sativum) & Fruit & Colds \\
\hline 28 & Singkong (Manihot utilissima) & Leaf & Overcome Anemia \\
\hline 29 & bidara (Ziziphus mauritiana) & Leaf & Antiseptic \\
\hline 30 & Rumput teki (Cyperus rotundus) & Leaf & Anti Cancer \\
\hline 31 & lengkuas (Alpiniagalanga) & Leaf & $\begin{array}{l}\text { Antipyretic, Anti- } \\
\text { Inflammatory, Uric } \\
\text { acid }\end{array}$ \\
\hline 32 & Kelakai (Stenochlaena palustris) & Leaf & Antihypertensive \\
\hline 33 & kunyit (Curcuma longa) & Rizhome & Antihistamine \\
\hline 34 & Daun ungu (Graptophyllum pictum) & Leaf & Anti hemorrhoids \\
\hline 35 & Bunga tasbih (Canna coccinea) & Leaf & Antipyretic \\
\hline 36 & Seledri (Apium graveolens) & Leaf & Antihypertensive \\
\hline 37 & Katuk (Sauropus androgynous) & Leaf & Facilitate breast milk \\
\hline 38 & Pandan (Pandanus amaryllifolius) & Leaf & Antidiabetes Mellitus \\
\hline 39 & Jeruk nipis (Citrus Aurantiinfolia) & Fruit & Antioxidant \\
\hline 40 & Pisang layap (Musa acuminata) & Leaf & Treatment for pioderma \\
\hline 41 & kemangi (Ocimum sanctum) & Leaf & Antihypertensive \\
\hline 42 & Cabai (Capsicum annaum) & Leaf & Treatmen for abses \\
\hline 43 & Betadin (Jatropha multifida Linn) & Leaf & Antiseptic \\
\hline 44 & Selasih (Ocimum basilicum) & Seed & Anti-Inflammatory \\
\hline 45 & Insulin (Smallanthus sonchifolius) & Leaf & Antidiabetes Mellitus \\
\hline
\end{tabular}




\begin{tabular}{llll}
\hline 46 & Kolang kaling (Aenga Pinata) & Fruit & $\begin{array}{l}\text { Uric acid, } \\
\text { Antihyperlipidemia }\end{array}$ \\
\hline 47 & Nanas (Ananas Comosus) & Fruit & Antihyperlipidemia \\
\hline 48 & Manggis (Gracinia mangoastana) & Rind & Antibiotik \\
\hline 49 & Ilalang (Imperata cylinrica) & Root & Kidney stones, Diuretik \\
\hline 50 & Kitolod (Hippobroma longiflora) & Flower & Treatment cataracts \\
\hline 51 & pegagan (Centella asiatica) & Leaf & $\begin{array}{l}\text { Antioxidant and } \\
\text { Antibiotik }\end{array}$ \\
\hline 52 & Lagundi (Vitex trifolia) & Leaf & $\begin{array}{l}\text { Anti-Inflammatory and } \\
\text { Antioxidant }\end{array}$ \\
\hline
\end{tabular}

Table 2. Plants part

\begin{tabular}{ccc}
\hline No & Plants part & Jumlah \\
\hline 1. & Leaf & 36 \\
\hline 2. & Others & 16 \\
\hline
\end{tabular}

\section{Comparison Chart of Plant Parts}

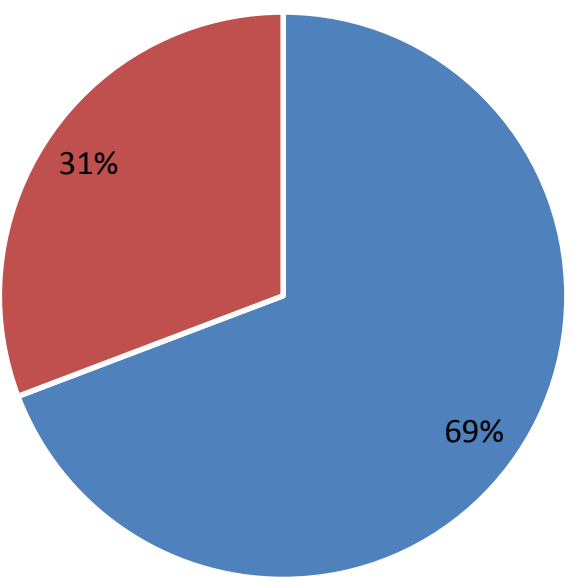

- Daun

- Lainnya

Fig 1. Comparison Chart of Plant Parts 


\section{Discussion}

This study aims to determine the community's habits in using plants as medicine. The people in South Kalimantan have a strong tradition of using plants to cure diseases. This tradition originates from the ancestors and nature of South Kalimantan, which is mostly forest and habitat of various plants. Respondents involved were 52 people and found 52 different plants with different benefits. There is 52 plants used, the leaves are the most widely used parts of the plant with different benefits. A total of 36 types of plants. The traditional use of leaves as a therapy might be due to the fact that leaves are part of plants that are easily picked and traditionally efficacious.

The results showed there were 52 plants that were often used as medicine by the people in Banjarmasin, Gambut, Danau Salak, and Banjarbaru. The results showed a variety of different types of plants but have the same potential to overcome certain health problems. Based on the results of the identification of all plants phytochemical identification tests have been carried out so that it can know the content of secondary metabolites that have the potential as drugs. The identification results show that not all types of plants have been tested preclinically related to their therapeutic activities so that not all plants can be scientifically proven for their medicinal uses. This shows that further research needs to be done in relation to the pre-clinical test of plant effectiveness.

Based on the identification of the most widely used plant parts are leaves. The results of this study are in accordance with previous studies conducted by Zuhud 2009 which showed the leaves are the most widely used plant parts. The results of this study are also in line with the research of Lestari Dewi in Tolai village in 2017 which shows that the most widely used plant parts are leaves. This shows in almost every area of the plant part that is most widely used is the leaves. The results of identification and study of journals show the leaves are the most widely used part of the plant because the leaves are easy to obtain and the processing is easier than other parts of the plant. The results of this study are in line with the 2012 Farhatul study.

Based on the research results it can be concluded that there are 52 types of plants that are used as medicine and the most widely used part is the leaves. The leaves develop from young to mature leaves. The difference in leaf age can affect the content of secondary metabolites of leaves. Young leaves are more often attacked by herbivores. Interactions between plants and environmental factors cause changes in metabolism, regulation of biochemical and physiological processes in plants. Plant defenses against pathogenic microorganisms depend on the innate immune system that is activated as a result of infection. The mechanisms that trigger the innate immune system by first basal immunity are activated as a result of the perception of patterns of microbial-related molecules through pattern recognition receptors located on the cell surface and effector-triggered immunity. Second, biosynthesis induced from bioactive secondary metabolites, specifically phytoalexins, is one of the mechanisms of plant defense against fungal infections [5] [6].

Another factor is because in general the leaves contain flavonoid compounds that function as regulators of photosynthesis, antimicrobial, antiviral, anti-insecticide, and protection against infection in wound tissue. 


\section{References}

[1] Patwardhan, B., Ethnopharmacology and drug discovery. Journal of ethnopharmacology, 100(1-2), 50-52. (2005).

[2] Stepp, J. R., \& Moerman, D. E., The importance of weeds in ethnopharmacology. Journal of ethnopharmacology, 75(1), 19-23. (2001).

[3] Baker, S. E., Edwards, R., \& Doidge, M., How many qualitative interviews is enough?: Expert voices and early career reflections on sampling and cases in qualitative research. (2012).

[4] Brinkmann, S. Qualitative interviewing. Oxford university press. (2013).

[5] Anna Wojakowska, Dorota Muth, Dorota Narożna, Cezary Mądrzak, Maciej Stobiecki, Piotr Kachlicki., Changes of phenolic secondary metabolite profiles in the reaction of narrow leaf lupin (Lupinus angustifolius) plants to infections with Colletotrichum lupini fungus or treatment with its toxin. Metabolomics. Volume 9, issue 3, 575-589. (2013).

[6] Tania Brenes-Arguedas, Matthew W. Horton, Phyllis D. Coley, John Lokvam, Rachel A. Waddell, Beatrice E. Meizoso-O'Meara, Thomas A. Kursar, Contrasting mechanisms of secondary metabolite accumulation during leaf development in two tropical tree species with different leaf expansion strategies. Oecologia. Volume 149, issue 1, 91-100. (2006).

[7] Farhatul. 2012. Potensi Tumbuhan Obat di Area kampus II UIN Alaudin Samata Gowa. Makasar

[8] Zuhud, E. A. M.,Hidayat., Potensi Hutan Tropika Indonesia sebagai penyangga bahan obat alam untuk kesehatan bangsa. Jakarta, 2009. 